\title{
Fermentation characteristics and bromatological composition of sweet sorghum bagasse silages
}

\author{
Características fermentativas e composição bromatológica de silagens do bagaço de \\ sorgo sacarino
}

\author{
GOMES-ROCHA, Françoise Mara ${ }^{1 *}$; EVANGELISTA, Antônio Ricardo ${ }^{1}$; ROCHA, \\ Norberto Silva ${ }^{2}$; SILVA, Tatiana Oliveira $\mathrm{da}^{2}$; ABREU, Luiza Rodrigues Alves ${ }^{3}$; \\ ORTÊNCIO, Marluci Olicio²; GUIMARÃES, Cintia Gonçalves ${ }^{1}$; BONFÁ, Caroline \\ Salezzi ${ }^{1}$
}

\footnotetext{
${ }^{1}$ Universidade Federal dos Vales do Jequitinhonha e Mucuri, Programa de Pós-Graduação em Biocombustíveis, Diamantina, Minas Gerais, Brasil.

${ }^{2}$ Universidade Federal dos Vales do Jequitinhonha e Mucuri, Programa de Pós-Graduação em Zootecnia, Unaí, Minas Gerais, Brasil.

${ }^{3}$ Universidade Federal de Minas Gerais, Escola Veterinária, Programa de Pós-Graduação em Zootecnia, Belo Horizonte, Minas Gerais, Brasil.

*Endereço para correspondência: francoise@zootecnista.com.br
}

\section{SUMARY}

The aim of this study was to evaluate conservation characteristics of sweet sorghum bagasse silages. The experiment was carried out at Fazenda Rio Manso, an experimental unit of the Federal University of the Jequitinhonha and Mucuri Valleys. Twenty-five sorghum cultivars with three replicates were used in a completely randomized design. The juice was extracted from the plant through an electric mill, generating bagasse, which was ground in a stationary silage machine, added of its panicles, and then introduced into experimental silos. Silages of the varieties BR505; CMSXS629; CMSXS635; CMSXS639; CMSXS643; CMSXS646; V82391 and V82392 presented lower rate of total dry matter recovery and, consequently, higher gas losses. The means of dry matter contents of bagasse and silage were 32.80 and $28.55 \%$, respectively. The cultivars BR501; XBSW80147; BR505; CMSXS629; CMSXS633; CMSXS634; CMSXS635; CMSXS639; CMSXS643; CMSXS644; CMSXS648; BRS601; Sugargraze; V82391; V82392 and V82393 showed higher crude protein levels. The cultivar CMSXS642 presented lower neutral and acid detergent fiber content: 39.23 and $19.23 \%$, respectively. The cultivar XBSW80147 showed lower acid detergent fiber content. Means of 3.49 for $\mathrm{pH}$ and 0.96 for water activity were recorded. The cultivars BR501 and BRS601 showed higher values of electrical conductivity: 0.93 and $0.95 \mathrm{~S} / \mathrm{cm}$, respectively. Higher levels of ammoniacal nitrogen were only observed in cultivars BR501; CMSXS629; CMSXS636; CMSXS648 and V82392. Sorghum bagasse silages presented adequate conservation inside the silos, according to the evaluated variables.

Keywords: ammoniacal nitrogen, conservation, byproduct, dry matter, $\mathrm{pH}$

\section{RESUMO}

Objetivou-se avaliar as características da conservação de silagens do bagaço de cultivares de sorgo sacarino. Conduziu-se o experimento na Fazenda Rio Manso, unidade experimental da Universidade Federal dos Vales do Jequitinhonha e Mucuri. Utilizaram-se 25 cultivares de sorgo sacarino, com três repetições, no delineamento inteiramente casualizado. Extraiu-se o caldo do corpo da planta através de uma moenda elétrica, gerando o bagaço, que logo foi moído em máquina ensiladora estacionária, adicionados de suas panículas, e depois introduzido com um bastão em silos experimentais. As silagens das cultivares: BR505; CMSXS629; CMSXS635; CMSXS639; CMSXS643; CMSXS646; V82391 e V82392 
apresentaram menor taxa de Recuperação Total de Matéria Seca e consequentemente maiores perdas por gases. Os teores médios de Matéria Seca do bagaço e da silagem foram de 32,80 e 28,55\% respectivamente. As cultivares BR501; XBSW80147; BR505; $\quad$ CMSXS629; CMSXS633; CMSXS634; CMSXS635; CMSXS639, CMSXS643; CMSXS644, CMSXS648; BRS601; Sugargraze; V82391; V82392 e V82393 apresentaram maiores teores de proteína bruta. Registrou-se média de 3,49 para o $\mathrm{pH}$ e de 0,96 para atividade da água. As cultivares BR501 e BRS601 apresentaram maiores valores de condutividade elétrica: 0,93 e $0,95 \mathrm{~S} / \mathrm{cm}$ respectivamente. Apenas nas cultivares BR501; CMSXS629; CMSXS636; CMSXS648 e V82392 notaram-se maiores teores de nitrogênio amoniacal. De acordo com as variáveis avaliadas neste estudo, as silagens do bagaço de cultivares de sorgo sacarino apresentaram uma adequada conservação do material dentro dos silos.

Palavras-chave: conservação, coproduto, matéria seca, nitrogênio amoniacal, $\mathrm{pH}$

\section{INTRODUCTION}

Sweet sorghum (Shorghum bicolor L. Moench) is an important crop used as bioethanol source (ROHOWSKY et al., 2012). Due to its $C_{4}$ photosynthetic system, it presents fast dry matter accumulation, resulting in high biomass production (TURHOLLOW et al., 2010). Different sweet sorghum cultivars are available to be used as bioenergy resource, resulting in technology and conversion (MARTINS et al., 2017). However, there is concern about the disposal of the remaining bagasse after juice extraction for biofuel production.

The supply of this bagasse for ruminants allows the association of agroenergy and livestock chains, minimizing environmental damages and undue discard of these products in nature (ABDALLA et al., 2008).

As ensiling is a suitable method for forage conservation (NAEINI et al.,
2014), it was performed with the intention of preserving this by-product for a longer period, providing potentially edible feed for ruminants.

Thus, each cultivar provides bagasse with differentiated characteristics and variations in yield and microorganisms at the ensiling process, which directly interferes with the fermentation pattern and results in different silages qualities (OLIVEIRA et al., 2009).

Therefore, this study aimed at evaluating dry matter recovery, gas losses, bromatological composition and fermentative characteristics of bagasse silages from different sweet sorghum cultivars.

\section{MATERIALS AND METHODS}

The cultivation of sorghum cultivars was conducted at the 2011/12 summer crop at Fazenda Rio Manso, an experimental unit of the Federal University of Jequitinhonha and Mucuri Valleys - UFVJM, located in the municipality of Couto de Magalhães de Minas - MG $\left(18^{\circ} 07^{\prime} \mathrm{S}\right.$ and $43^{\circ} 47^{\prime} \mathrm{W}$, at 726 metros of altitude) average annual rainfall of $1,269 \mathrm{~mm}$, average annual temperature of $19.4^{\circ} \mathrm{C}$.

The trials were carried out in a completely randomized design, with 25 treatments, three replicates, totaling 75 experimental units (EU), corresponding to cultivars of sweet sorghum, from the breeding program of Embrapa Maize and Sorghum. The following cultivars were evaluated: BR501; XBSW80007; XBSW80147; BR505; BRS506; BRS507; CMSXS629; CMSXS630; CMSXS633; CMSXS634; CMSXS635; CMSXS636; CMSXS637; CMSXS639; CMSXS642; CMSXS643; CMSXS644; CMSXS646; CMSXS647; CMSXS648; 
BRS601; Sugargraze; V82391; V82392 and V82393.

Seeding was performed in January and in May, 102 days later, harvest was carried out. The average height of the cultivars were 2.7 meters. The whole plants went through the electric mill for juice extraction and bioethanol production, generating bagasse. Maintaining the experimental arrangement of the treatments in their respective experimental units, the bagasse was milled for ensiling, added of its panicles, with an average particle size of 1 to 2 centimeters, using a stationary silage machine.

The bagasse of the cultivars was ensiled in experimental silos composed of PVC tubes, with capacity of $2.5 \mathrm{~kg}$, provided with Bunsen valve adapted to their lids, to allow fermentation gases to escape. The forage compaction was performed manually with a stick, obtaining an average specific mass of $600 \mathrm{~kg} / \mathrm{m}^{3}$ of natural matter.

The silos were opened in September 2013. They were weighed again and the dry matter recovery, gas losses and the average particle size of the silages were evaluated, according to the methodology described by Jobim et al. (2007).

The samples used for analysis of the fermentation characteristics, bromatological composition and average particle size were collected by separating the contaminated parts with molds in the upper part and contaminated with effluent in the lower part, using only the silage from the middle part of the silo, which was homogenized and sampled.

For the determination of the bromatological composition, samples of approximately $300 \mathrm{~g}$ of each silo were collected, which were pre-dried in a forced-air oven at $55^{\circ}$ for 72 hour, and the samples milled in Willey mill with a 1 $\mathrm{mm}$ sieve. The dry matter (DM) contents of bagasse and silage, crude protein (CP), neutral detergent insoluble fiber (NDF) and acid detergent insoluble fiber (ADF) were analyzed in the milled samples (DETMANN et al., 2012).

At the same time, samples of $25 \mathrm{~g}$ of fresh silage from each silo were collected and $250 \mathrm{~mL}$ of distilled water were added. They remained in resting for $1 \mathrm{~h}$ to read $\mathrm{pH}$ (CHERNEY \& CHERNEY, 2003) and to determine electrical conductivity (KRAUS et al,. 1997). A fast reading water activity meter was used to analyze water activity (Aw), according to Greenhill (1964). To analyze the ammoniacal nitrogen, part of the fresh material was pressed in a hydraulic press for extraction of the silage juice, which was preserved with $0.036 \mathrm{~N}(0.32 \%)$ sulfuric acid and frozen for further determination of the ammoniacal nitrogen content through distillation with magnesium oxide (AOAC, 1995).

Data were submitted to analysis of variance, using the statistical program GENES (Cruz, 2006), and the means were grouped and compared by the Scott and Knott test at 5\% significance.

\section{RESULTS AND DISCUSSION}

It was observed that the silages of the varieties $\quad$ BR505; $\quad$ CMSXS629; CMSXS635; CMSXS639; CMSXS643; CMSXS646; V82391 and V82392 presented lower rate of total DM recovery and consequently higher gas losses (Table 1). For Pahlow et al. (2003), the higher the recovery percentage of DM, the greater the efficiency of microorganisms that are desirable for the fermentation, reducing the total losses of DM. Gas losses are unavoidable and difficult to reduce because they occur during the fermentation process of forage ensiling, and can be caused by the manifestation of 
bacteria of the genus Clostridium, which act on lactate or sugars, producing butyric acid and $\mathrm{CO}_{2}$ (JOBIM et al., 2007).

The overall mean of APS was $12.52 \mathrm{~mm}$ $(\mathrm{P}>0.05)$, which is an ideal size for good quality fermentation (Table 1). In addition, small particles in the manufacture of silages, facilitate the compaction in the silage process and decrease physical losses during the silos opening.

Tabela 1. Mean values of dry matter recovery; gas losses and average particle size (APS) of sweet sorghum bagasse silages

\begin{tabular}{ccccc}
\hline Treatments & Cultivars & \%DM recovery & Gas losses \% & APS (mm) \\
\hline 1 & BR501 & $90.77^{\mathrm{a}}$ & $9.2^{\mathrm{b}}$ & 13.71 \\
2 & XBSW80007 & $87.30^{\mathrm{a}}$ & $7.35^{\mathrm{b}}$ & 10.06 \\
3 & XBSW80147 & $91.58^{\mathrm{a}}$ & $8.42^{\mathrm{b}}$ & 10.34 \\
4 & BR505 & $84.60^{\mathrm{b}}$ & $15.08^{\mathrm{a}}$ & 15.12 \\
5 & BRS506 & $88.71^{\mathrm{a}}$ & $11.25^{\mathrm{b}}$ & 11.39 \\
6 & BRS507 & $93.08^{\mathrm{a}}$ & $6.92^{\mathrm{b}}$ & 9.16 \\
7 & CMSXS629 & $77.34^{\mathrm{b}}$ & $22.66^{\mathrm{a}}$ & 9.76 \\
8 & CMSXS630 & $86.31^{\mathrm{a}}$ & $13.69^{\mathrm{b}}$ & 15.62 \\
9 & CMSXS633 & $89.02^{\mathrm{a}}$ & $10.98^{\mathrm{b}}$ & 10.55 \\
10 & CMSXS634 & $86.94^{\mathrm{a}}$ & $13.06^{\mathrm{b}}$ & 9.80 \\
11 & CMSXS635 & $80.17^{\mathrm{b}}$ & $19.83^{\mathrm{a}}$ & 15.94 \\
12 & CMSXS636 & $90.77^{\mathrm{a}}$ & $9.23 \mathrm{~b}$ & 11.42 \\
13 & CMSXS637 & $87.03^{\mathrm{a}}$ & $12.97^{\mathrm{b}}$ & 8.42 \\
14 & CMSXS639 & $75.27^{\mathrm{b}}$ & $24.73^{\mathrm{a}}$ & 10.42 \\
15 & CMSXS642 & $92.90^{\mathrm{a}}$ & $7.1^{\mathrm{b}}$ & 11.63 \\
16 & CMSXS643 & $81.68^{\mathrm{b}}$ & $18.32^{\mathrm{a}}$ & 10.42 \\
17 & CMSXS644 & $96.86^{\mathrm{a}}$ & $3.14^{\mathrm{b}}$ & 11.26 \\
18 & CMSXS646 & $77.29^{\mathrm{b}}$ & $22.71^{\mathrm{a}}$ & 14.69 \\
19 & CMSXS647 & $88.68^{\mathrm{a}}$ & $11.32^{\mathrm{b}}$ & 21.51 \\
20 & CMSXS648 & $92.88^{\mathrm{a}}$ & $7.12^{\mathrm{b}}$ & 19.66 \\
21 & BRS601 & $94.39^{\mathrm{a}}$ & $5.61^{\mathrm{b}}$ & 14.63 \\
22 & Sugargraze & $88.84^{\mathrm{a}}$ & $9.86^{\mathrm{b}}$ & 10.55 \\
23 & V82391 & $77.65^{\mathrm{b}}$ & $22.35^{\mathrm{a}}$ & 13.19 \\
24 & V82392 & $81.19^{\mathrm{b}}$ & $18.81^{\mathrm{a}}$ & 9.58 \\
25 & V82393 & $90.82^{\mathrm{a}}$ & $9.18^{\mathrm{b}}$ & 14.15 \\
\hline & CV $\%)$ & 53.18 & 35.30 \\
& Overall mean & 0.0979 & 12.84 & 12.52 \\
\hline & P-value & 0.1837 & 0.0683 \\
\hline
\end{tabular}

*Means in the same column followed by different lowercase letters differ from each other within each factor by the Scott and Knott test, at $5 \%$ probability.

From the results presented in Table 2, it can be observed that there was no difference between the dry matter content (\% DM) of sorghum bagasse, with overall mean of $32.80 \%(\mathrm{P}>0.05)$. It can be justified by the juice extraction from the plant to produce ethanol. The dry matter content of the forage is one of the main factors in the silage process, since it will determine the type of fermentation that will develop inside the silo (OLIVEIRA et al., 2009).

The MS content is considered satisfactory for a well-conserved silage (Table 1), with mean of $28.55 \%(\mathrm{P}>0.05)$, close to that found by Vidya et al. (2016) that obtained content of $34.83 \%$, and lower than that recorded by Kumari et al. 
(2011), who observed a content of $42.10 \%$ for $\mathrm{DM}$ in exclusive bagasse silages.

The cultivars BR501; XBSW80147; BR505; CMSXS629, CMSXS633, CMSXS634; CMSXS635, CMSXS639, CMSXS643, CMSXS644, CMSXS648, BRS601, Sugargraze, V82391, V82392 and V82393, presented higher crude protein content: $7.14 ; 7.15 ; 6.93 ; 6.50$; $6.51 ; 6.67 ; 6.98 ; 6.79 ; 6.67 ; 6.75 ; 6.64$; $6.91 ; 6.82 ; 6.54 ; \quad 6.62$ and 6.69 respectively $(\mathrm{P}<0.05)$. These values are close to the ones found by Kumari et al. (2011), with mean of 7.27.

The cultivar CMSXS642 presented lower neutral and acid detergent fiber content: 39.23 and $19.23 \%$, respectively. The cultivar XBSW80147 had lower acid detergent fiber content. Ávila et al. (2013) reported levels of $63 \% \mathrm{NDF}$ and $41.4 \%$ $\mathrm{ADF}$ in the bagasse silages of sorghum cultivars.

Table 2. Mean values of: Dry matter (DM) of the bagasse and silage; Crude Protein (PB); Neutral Detergent Fiber (NDF); Acid Detergent Fiber (ADF) of sweet sorghum bagasse silages

\begin{tabular}{|c|c|c|c|c|c|c|}
\hline Treatments & Cultivars & \%DM bagasse & \%DM silage & $\% \mathrm{CP}$ & $\% \mathrm{NDF}$ & $\% \mathrm{ADF}$ \\
\hline 1 & BR501 & 32.29 & 29.00 & $7.14^{\mathrm{a}}$ & $40.74^{\mathrm{i}}$ & $20.67^{\mathrm{i}}$ \\
\hline 2 & XBSW80007 & 31.55 & 27.94 & $6.09^{\mathrm{b}}$ & $51.87^{\mathrm{c}}$ & $28.44^{\mathrm{a}}$ \\
\hline 3 & XBSW80147 & 36.03 & 30.28 & $7.15^{\mathrm{a}}$ & $40.57^{\mathrm{i}}$ & $19.16^{\mathrm{j}}$ \\
\hline 4 & BR505 & 35.81 & 29.97 & $6.93^{\mathrm{a}}$ & $49.16^{\mathrm{e}}$ & $24.27^{\mathrm{f}}$ \\
\hline 5 & BRS506 & 30.29 & 27.86 & $6.28^{\mathrm{b}}$ & $48.90^{\mathrm{e}}$ & $25.18^{\mathrm{e}}$ \\
\hline 6 & BRS507 & 32.10 & 30.13 & $6.05^{\mathrm{b}}$ & $46.77^{\mathrm{g}}$ & $24.74^{\mathrm{f}}$ \\
\hline 7 & CMSXS629 & 35.32 & 27.70 & $6.50^{\mathrm{a}}$ & $47.76^{\mathrm{f}}$ & $26.69^{\mathrm{c}}$ \\
\hline 8 & CMSXS630 & 31.79 & 27.67 & $5.96^{\mathrm{b}}$ & $47.51^{\mathrm{f}}$ & $24.12^{\mathrm{f}}$ \\
\hline 9 & CMSXS633 & 32.83 & 29.21 & $6.51^{\mathrm{a}}$ & $49.24^{\mathrm{e}}$ & $26.22^{\mathrm{d}}$ \\
\hline 10 & CMSXS634 & 30.63 & 27.15 & $6.67^{\mathrm{a}}$ & $51.93^{\mathrm{c}}$ & $26.78^{\mathrm{c}}$ \\
\hline 11 & CMSXS635 & 34.47 & 27.77 & $6.98^{\mathrm{a}}$ & $53.91^{\mathrm{b}}$ & $28.87^{\mathrm{a}}$ \\
\hline 12 & CMSXS636 & 31.23 & 28.84 & $6.26^{\mathrm{b}}$ & $44.90^{\mathrm{h}}$ & $22.08^{\mathrm{h}}$ \\
\hline 13 & CMSXS637 & 33.51 & 29.42 & $6.19^{\mathrm{b}}$ & $45.17^{\mathrm{h}}$ & $23.36^{\mathrm{g}}$ \\
\hline 14 & CMSXS639 & 31.79 & 24.46 & $6.79^{\mathrm{a}}$ & $47.44^{\mathrm{f}}$ & $21.77^{\mathrm{h}}$ \\
\hline 15 & CMSXS642 & 31.48 & 29.50 & $5.53^{\mathrm{b}}$ & $39.23^{\mathrm{j}}$ & $19.23^{\mathrm{j}}$ \\
\hline 16 & CMSXS643 & 36.52 & 29.23 & $6.67^{\mathrm{a}}$ & $40.22^{\mathrm{i}}$ & $21.00^{\mathrm{i}}$ \\
\hline 17 & CMSXS644 & 29.17 & 28.71 & $6.75^{\mathrm{a}}$ & $49.17^{\mathrm{e}}$ & $26.73^{\mathrm{c}}$ \\
\hline 18 & CMSXS646 & 36.12 & 28.20 & $5.98^{\mathrm{b}}$ & $48.55^{\mathrm{e}}$ & $25.51^{\mathrm{e}}$ \\
\hline 19 & CMSXS647 & 29.31 & 26.39 & $6.32^{\mathrm{b}}$ & $49.75^{\mathrm{e}}$ & $26.22^{\mathrm{d}}$ \\
\hline 20 & CMSXS648 & 33.08 & 31.31 & $6.64^{\mathrm{a}}$ & $46.77^{\mathrm{g}}$ & $26.79^{\mathrm{c}}$ \\
\hline 21 & BRS601 & 28.08 & 26.82 & $6.91^{\mathrm{a}}$ & $54.22^{\mathrm{b}}$ & $26.56^{\mathrm{c}}$ \\
\hline 22 & Sugargraze & 32.70 & 28.88 & $6.82^{\mathrm{a}}$ & $54.03^{\mathrm{b}}$ & $25.86^{\mathrm{d}}$ \\
\hline 23 & V82391 & 37.43 & 29.31 & $6.54^{\mathrm{a}}$ & $54.39^{\mathrm{b}}$ & $28.33^{\mathrm{a}}$ \\
\hline 24 & V82392 & 35.09 & 28.96 & $6.62^{\mathrm{a}}$ & $55.28^{\mathrm{a}}$ & $27.68^{\mathrm{b}}$ \\
\hline \multirow[t]{4}{*}{25} & V82393 & 31.44 & 28.96 & $6.69^{\mathrm{a}}$ & $50.83^{\mathrm{d}}$ & $27.42^{\mathrm{c}}$ \\
\hline & CV (\%) & 14.66 & 9.88 & 6.03 & 1.1001 & 1.9314 \\
\hline & Overall mean & 32.80 & 28.55 & 6.52 & 48.33 & 24.95 \\
\hline & P-value & 0.7081 & 0.7628 & 0.0346 & 0.0 & 0.0 \\
\hline
\end{tabular}

*Means in the same column, followed by different lowercase letters, differ among each other within each factor by the Scott and Knott test at the 5\% probability. 
There was no significant differences among the silages for $\mathrm{pH}$ values, with mean of $3.49(\mathrm{P}>0.05)$ (Table 3), which leads to acid silages, which may have helped to maintain an adjusted internal situation which may have helped to preserve an internal situation adjusted for maintenance of the nutrients until the silos opening. Acidity is an important point in the process of assessing the quality of silages. According to Evangelista et al. (2005), the silages are classified as excellent when they present $\mathrm{pH}$ lower than 4.6 for the range of 26 to $35 \%$ DM content.
The silages of the cultivars BR501 and BRS601 presented higher values of electrical conductivity (EC), 0.93 and $0.95 \mathrm{~S} / \mathrm{cm}(\mathrm{P}<0.05)$ respectively (Table $3)$, demonstrating that there was a greater cell lysis, and consequently, higher ions loss in effluents. The measurement of EC is the ability of water to conduct electric current and evaluates the intensity of the cellular rupture in the forage subjected to the cut and the consequent extravasation of ions to the solution (KRAUS et al., 1997).

Table 3. Mean values of $\mathrm{pH}$, eletrical conductivity (EC); wateractivity (Aw) and Ammoniacal nitrogen $(\% \mathrm{~N}-\mathrm{NH} 3 / \mathrm{N}-\mathrm{Total})$ of sweet sorghum bagasse silages

\begin{tabular}{cccccc}
\hline Treatments & Cultivars & $\mathrm{pH}$ & $\mathrm{EC}(\mathrm{S} / \mathrm{cm})$ & $\mathrm{Aw}$ & $\mathrm{N}-N H_{3}$ \\
\hline 1 & BR501 & 3.41 & $0.93^{\mathrm{a}}$ & 0.95 & $4.20^{\mathrm{a}}$ \\
2 & XBSW80007 & 3.43 & $0.81^{\mathrm{c}}$ & 0.96 & $2.37^{\mathrm{b}}$ \\
3 & XBSW80147 & 3.52 & $0.85^{\mathrm{b}}$ & 0.96 & $3.30^{\mathrm{b}}$ \\
4 & BR505 & 3.56 & $0.85^{\mathrm{b}}$ & 0.95 & $2.98^{\mathrm{b}}$ \\
5 & BRS506 & 3.48 & $0.88^{\mathrm{b}}$ & 0.96 & $3.03^{\mathrm{b}}$ \\
6 & BRS507 & 3.48 & $0.76^{\mathrm{c}}$ & 0.96 & $3.09^{\mathrm{b}}$ \\
7 & CMSXS629 & 3.46 & $0.84^{\mathrm{b}}$ & 0.96 & $3.83^{\mathrm{a}}$ \\
8 & CMSXS630 & 3.41 & $0.78^{\mathrm{c}}$ & 0.96 & $3.14^{\mathrm{b}}$ \\
9 & CMSXS633 & 3.49 & $0.81^{\mathrm{c}}$ & 0.95 & $3.35^{\mathrm{b}}$ \\
10 & CMSXS634 & 3.45 & $0.79^{\mathrm{c}}$ & 0.96 & $3.14^{\mathrm{b}}$ \\
11 & CMSXS635 & 3.40 & $0.79^{\mathrm{c}}$ & 0.96 & $2.93^{\mathrm{b}}$ \\
12 & CMSXS636 & 3.44 & $0.76^{\mathrm{c}}$ & 0.95 & $4.15^{\mathrm{a}}$ \\
13 & CMSXS637 & 3.49 & $0.72^{\mathrm{c}}$ & 0.95 & $3.40^{\mathrm{b}}$ \\
14 & CMSXS639 & 3.54 & $0.77^{\mathrm{c}}$ & 0.95 & $3.46^{\mathrm{b}}$ \\
15 & CMSXS642 & 3.49 & $0.83^{\mathrm{b}}$ & 0.95 & $3.35^{\mathrm{b}}$ \\
16 & CMSXS643 & 3.44 & $0.78^{\mathrm{c}}$ & 0.95 & $2.34^{\mathrm{b}}$ \\
17 & CMSXS644 & 3.47 & $0.78^{\mathrm{c}}$ & 0.95 & $3.19^{\mathrm{b}}$ \\
18 & CMSXS646 & 3.42 & $0.77^{\mathrm{c}}$ & 0.95 & $2.82^{\mathrm{b}}$ \\
19 & CMSXS647 & 3.48 & $0.81^{\mathrm{c}}$ & 0.96 & $3.25^{\mathrm{b}}$ \\
20 & CMSXS648 & 3.46 & $0.79^{\mathrm{c}}$ & 0.95 & $4.15^{\mathrm{a}}$ \\
21 & BRS601 & 3.58 & $0.95^{\mathrm{a}}$ & 0.96 & $3.09^{\mathrm{b}}$ \\
22 & Sugargraze & 3.56 & $0.77^{\mathrm{c}}$ & 0.95 & $2.98^{\mathrm{b}}$ \\
23 & V82391 & 3.55 & $0.71^{\mathrm{c}}$ & 0.96 & $3.19^{\mathrm{b}}$ \\
25 & V82392 & 3.63 & $0.80^{\mathrm{c}}$ & 0.96 & $4.36^{\mathrm{a}}$ \\
& V82393 & 3.52 & $0.81^{\mathrm{c}}$ & 0.96 & 0.0146 \\
\hline
\end{tabular}

*Means in the same column, followed by different lowercase letters, differ from each other within each factor by the Scott and Knott test at 5\% probability. 
There was no significant difference in water activity (Aw) in this study $(\mathrm{P}>$ $0.05)$, resulting in mean value of 0.96 (Table 3). The highest value of Aw indicates that the action of microorganisms can be intensified, considering that the microbial digestion of the nutrients occurs in the extracellular environment. Water is an important vehicle for this hydrolysis process. According to Ditchfield (2000), the term water activity was created to determine water available for microbial growth and reactions that could deteriorate food. The value of Aw indicates the water level in its free form in the materials and is expressed in a scale from 0 (zero) to 1.0. Zero is considered for water-free materials and 1.0 for water in its liquid form. Consequently, the mean of 0.96 favors the microbial activity in these silages.

A significant difference $(\mathrm{P}<0.05)$ was observed for ammoniacal nitrogen $(\mathrm{N}$ $\mathrm{NH}_{3}$ ) contents only in cultivars BR501; CMSXS629; CMSXS636; CMSXS648 and V82392 higher levels were observed: $4.20,3.83,4.15$ and $4.36 \%$, respectively. The silages of this study can be classified as of very good quality, according to Ribeiro et al. (2007), since they presented a relation$\mathrm{NH}_{3} \mathrm{NT}$ lower than $10 \%$.

Sweet sorghum bagasse silages presented an adequate conservation of the material inside the silos. Minimum losses, which helped to maintain a good bromatological composition and stable fermentative characteristics, were recorded until the silos opening.

\section{ACKNOWLEGEMENTS}

To Coordination for the Improvement of Higher Education Personnel (CAPES), to National Council for Scientific and Technological Development ( CNPq), to Embrapa Maize and
Sorghum and University of the Jequitinhonha and Mucuri Valleys (UFVJM).

\section{REFERENCES}

ABDALLA, L.A.; SILVA FILHO, J.C.; GODOI, A.R.; CARMO, C.A.; EDUARDO, J.L.P. Utilização de subprodutos da indústria de biodiesel na alimentação de ruminantes. Revista Brasileira de Zootecnia, v.37, p.260258, 2008. Supl. especial.

ASSOCIATION OFFICIAL ANALITICAL CHEMISTS - AOAC. Official methods of analysis. 14.ed. Washington, 1995. 101p.

CHERNEY, J.H.; CHERNEY, D.J.R. Assessing silage quality. In: BUXTON, D.R.; MUCK, R.E.; HARRISON, J.H. (Eds). Silage science and technology. 1.ed. Madison: American Society of Agronomy, 2003. p.141-198.

AVILA, S.C.; MARTINS, A.A.; KOZLOSKI, G.V.; ORLANDI, T.; MEZZOMO, M.P.; STEFANELLO, C.M.; HENTZ, F. CASTAGNINO, P. Sunflower meal supplementation to wethers fed sorghum bagasse silage. Ciência Rural, v.42, n.7, p.1245-1250, 2013.

CRUZ, CD. Programa Genes:

biometria. Viçosa: UFV, 2006. 452p.

DETMANN, E. ; SOUZA, M.A.; VALADARES FILHO, S.C.; QUEIROZ, A.C.; BERCHIELLI, T.T.; SALIBA, E.O.S.; CABRAL, L.S.; PINA, D.S.; LADEIRA, M.M.; AZEVEDO, J.A.G. Métodos para análise de alimentos INCT - Ciência Animal. 1.ed. Visconde do Rio Branco: Suprema, 2012. 214p. 
DITCHFIELD, C. Estudos dos métodos para a medida da atividade de água. 2000. 195p. Dissertação (Mestrado em Engenharia) - Escola Politécnica, Universidade de São Paulo, São Paulo.

EVANGELISTA, A.R.; ABREU, J.G.; AMARAL, P.N.C.; PEREIRA, R.C.; SALVADOR, F.M.; LOPES, J.; SOARES, L.Q. Chemical composition of sorghum silage (Sorghum bicolor (L.) Moench) enriched with leucaena forage (Leucaena leucocephala (LAM.) DEWIT). Ciência e Agrotecnologia, v.29, n.2, p.429-435, 2005.

GREENHILL, W.L. Plant juice in relation to silage fermentation. Journal of the British Grassland Society, v.19, p.336-339, 1964.

JOBIM, C.C.; NUSSIO, L.G.; REIS, R.A.; SCHMIDT, P. Avanços metodológicos na avaliação da qualidade da forragem conservada.

Revista Brasileira de Zootecnia, v.36, p.101-119, 2007. Supl. especial.

KRAUS, T.J.; KOEGER, R.G.; STRAUB, R.J.; SHINNERS, K.J. Leachate conductivity as an index for quantifying level of forage conditioning. In: ASAE ANNUAL INTERNATIONAL MEETING, 1997, Minneapolis. Proceedings...

Minneapolis: ASAE, 1997. 12p.

KUMARI, N.N; REDDY, Y.R.; BLUMMEL, M.; NAGALAKSHMI, D.; MONICA, T. Effect of feeding sweet sorghum bagasse silage with or without chopping on nutrient utilization in deccani sheep. Animal Nutrition and Feed Technology, v.13, p.243-249, 2013.
LAMMERS, B.P.; BUCKMASTER, D.R.; HEINRINCHS, A.J. A simple method for the analysis of particle size of forage and total mixed rations.

Journal of Dairy Science, v.79, p.922928, 1996.

MARTINS, A.M.; PARRELLA, R.A.; LOPES, D.C.; SCHAFFERT, R.E.; PARRELLA, N.N.L.D.; NEVES, W.S.; SILVA, A.P.C.M. Período de utilização industrial de cultivares de sorgo sacarino visando a produção de etanol.

Revista Brasileira de Milho e Sorgo, v16, n.2, p. 217-231, 2017.

NAEINI, S.Z.; KHORVASH,M.; ROWGHANI, E.; BAYAT, A.; NIKOUSEFAT, Z.E. Effects of urea and molsses supplementation on cheminical composition, protein fractionation and fermetation characteristics of sweet sorghum and bagasse silages as alternative silage crop compared with maize silage in the arid áreas. Research Opinions in Animal and Veterinary Sciences, v.4, n.6, p.343-352, 2014.

OLIVEIRA, R.P.; FRANÇA, A.F.S.; SILVA, A.G.; MIYAGI, E.S.; OLIVEIRA, E.R.; PERÓN, H.J.M.C. Composição bromatológica de quatro híbridos de sorgo forrageiro sob doses de nitrogênio. Ciência Animal Brasileira, v.10, n.4, p.1003-1012, 2009.

PAHLOW, G.; MUCK, R.E.; DRIEHUUS, F. Microbiology of ensiling. In: SILAGE SCIENCE AND TECHNOLOGY, 42., Madison. Proceedings... Madison: ASCSSASSSA, 2003. p.31-93. 
RIBEIRO, C.G.M.; GONÇALVES,

L.C.; RODRIGUES, J.A.S.;

RODRIGUEZ, N.M.; BORGES, I.;

BORGES, A.L.C.C.; RIBEIRO

JUNIOR, G.O. Padrão de fermentação

da silagem de cinco genótipos de sorgo.

Arquivo Brasileiro de Medicina

Veterinária e Zootecnia, v.59, n.6, p.1531-1537, 2007.

ROHOWSKY, B. Feasibility of simultaneous saccharification and juice co-fermentation on hydrothermal preated sweet sorghum bagasse for ethanol prodution. Applied Energy, v.2, p.1-9, 2012.

SCHMIDT, P. Perdas fermentativas na ensilingm, parâmetros disgestivos e desempenho de bovinos de corte alimentados com rações contendo silagens de cana-de-açúcar. 2006. 228p. Tese (Doutorado em Agronomia) - Escola Superior de Agricultura Luiz de Queiroz, Universidade de São Paulo, Piracicaba.

TURHOLLOW, A.F.; WEBB, E.G.; DOWNING, M.E. Review of sorghum production pratices: applications for bioenergy. Environmental Sciences Division. Tennesse: Oak Ridge National Laboratory, 2010.

VIDYA, B.; REDDY, Y.R.; RAO, S.; REDDY, R.V.; KUMARI, N.N.; BLUMMEL, M. Effect of supplementation of concentrate to sweet sorghum gabsse with leaf residue on nutrient utilization and nitrogen balance in native sheep. Idian Journal Animal Research, v.50, n.3, p387-391, 2016.

Receipt date: $31 / 01 / 2018$

Approval date: 07/05/2018 